SECTION 11. Biology. Ecology. Veterinary.

Kyzlasova Karina Stanislavovna

5th year student, Department of Zoology and Bioecology Khakass state University named after. N.F. Katanov, Abakan, Russia kyzlasovakarina@mail.ru

\title{
SPECIES COMPOSITION OF BIRDS, INHABITING THE LAKE ULUGKOL AND ITS SURROUNDINGS
}

\begin{abstract}
The main goal of the study was to examine the population of birds in the lake Ulugkol and its surroundings. Novelty of research consists in the fact that such researches for the study of bird population in the given territory for the last 10 years were carried out for the first time.
\end{abstract}

Keywords: group, family, avifauna.

\section{ВИДОВОЙ СОСТАВ ПТИЦ, ОБИТАЮЩИХ НА ОЗЕРЕ УЛУГКОЛЬ И ЕГО ОКРЕСТНОСТЯХ}

Аннотация: Целью исследования явилось изучение населения птич озера Улугколь и его окрестностей. Новизна исследования заключается в том, что подобные исследования по изучению населения птии на данной территории за последние 10 лет проводились впервые.

Ключевые слова: отряд, семейство, авифауна.

На основе ретроспективного анализа составлен аннотированный список видов птиц, обитающих на участке «Камызякская степь с озером Улугколь» Государственного природного заповедника «Хакасский».

Участок «Камызякская степь с озером Улугколь» расположен в Уйбатской степи и Карасукской степях Приабаканского (Центрально-Хакасского) степного округа. Площадь участка составляет 4789,3 га [1, с.23.].

Озеро Улугколь - бессточный, горько-солёный, мелководный водоём с преобладающими глубинами до 1 м. Со всех сторон его окружает степь, как правило, мелкодерновинно-злаковая. Южное побережье представлено невысокой каменистой горной грядой, достигающей 50 м над поверхностью озера, а северное и западное, где в Улугколь впадают три небольших ручья, заняты обширным можачино-кочкарниковым болотом с куртинами тростника, рогоза и камыша. Здесь обычны солончаки. Береговая полоса занята грязевыми отмелями. В окрестностях озера Улугколь имеются более мелкие, небольшие озёра с разной степенью минерализации воды [2, с.56].

Для наблюдений использовали бинокль БПЦ-10. Определение птиц проводили визуально и по голосам. Названия видов, подвидов и их систематическое положение приведены по Л. С. Степаняну [3, с. 35]

За период исследования, в весенний и осенний период, нами отмечено пребывание 69 видов птиц на озере Улугколь, относящихся к 8 отрядам из 21 семейства (по системе Л. С. Степаняна, 2003) (рис. 1) [6, с. 23]. образом:

В систематическом отношении данные отряды представлены следующим

Отряды Поганкообразные (Podicipediformes) и Гусеобразные (Anseriformes) представлены по одному семейству Поганковые (1 вид) и Утиные (14 видов) соответственно. В Красную книгу Республики Хакасия (2004) входят некоторые представители отряда Гусеобразные, это - лебедь-кликун, пеганка, горбоносый турпан. 
Из представителей отряда Соколообразные (Falconiformes) на исследуемой территории обитают представители двух семейств: Ястребиные (6 видов) и Соколиные (6 видов). В Красную книгу Республики Хакасия (2004) из семейства Ястребиные входят - мохноногий курганник, могильник. Из семейства Соколиные - балобан, сапсан и дербник.

Отряд Курообразные (Galliformes) представлен одним семейством Фазановые (1 вид). Отряд Журавлеообразные (Gruiformes) представлен двумя семействами: Журавлиные (1 вид) и Пастушковые (1 вид). В Красную книгу Республики Хакасия (2004) входит представитель семейства Журавлиные - красавка.

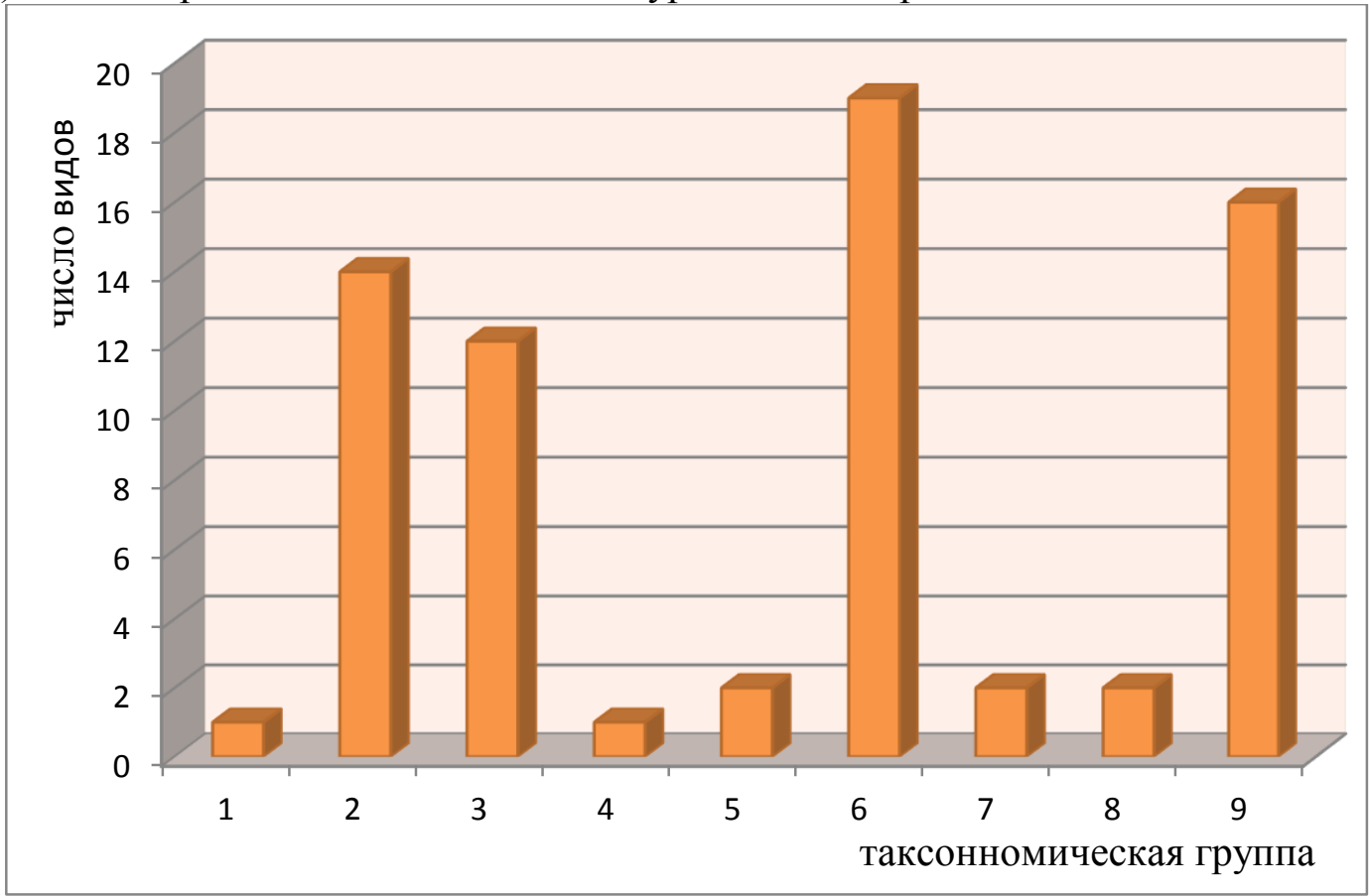

Рисунок 1 - Соотношение таксономических групп птиц, обитающих на участке «Камызякская степь с озером Улугколь» (2012-2013 гг.):

1 - Podicipediformes, 2 - Anseriformes, 3 -Falconiformes, 4 - Galliformes,

5 - Gruiformes, 6 -Charadriiformes, 7 -Strigiformes, 8 -Apodiformes, 9 - Passeriformes

Отряд Ржанкообразные (Charadriiformes) представлен четырьмя семействами Ржанковые (3 вида), Шилоклювковые (2 вид), Бекасовые (10 видов) и Чайковые (4 вида). Этот отряд представлен наибольшим количеством видов, обитающих на исследуемой территории. В Красную книгу Республики Хакасия (2004) из представленных семейств входят 2 вида- шилоклювка и длиннопалый песочник. Чернозобик включен только в Красную книгу Российской Федерации (2004) и не включен в список охраняемых видов региональной книги.

Отряд Совообразные (Strigiformes) представлен одним семейством Совиные (2вида). Отряд Стрижеобразные Apodiformes представлен одним семейством Стрижиные (2 вида).

Отряд Воробьинообразные (Passeriformes) лидирует по числу семейств и представлен семью семействами: Ласточковые (2 вида) [7, с.34; 8, с. 67], Жаворонковые (3 вида), Трясогузковые (4 вида), Скворцовые (1 вид), Врановые (3 вида), Мухоловковые (2 вида), Воробьиные (1 вид).

Таким образом, из представленного списка 7 видов птиц внесены в Красную книгу Российской Федерации (2001) и Республики Хакасия (2004), один вид внесен 
только в Красную книгу Российской Федерации (2001) и еще 16 видов внесены только в Красную книгу Республики Хакасия (2004).

По числу видов, обитающих на исследуемой территории лидируют отряды Charadriiformes - 28\% (19 видов), Passeriformes - 23\% (16 видов), Anseriformes - 20\% (14 видов) и Falconiformes -17\% (12 видов). На остальные отряды в сумме приходится $12 \%$ (8 видов)

В то время как для авифауны Республики Хакасия $[5$, с.78 ; 3,c.56 ] и АлтайСаянского экорегиона в целом [2, с. 96] характерно преобладание представителей отряда Passeriformes, далее по степени значимости следуют представители отрядов Charadriiformes, Anseriformes и Falconiformes.

Таким образом, согласно составленному аннотированному списку на участке «Камызякская степь с озером Улугколь» ГПЗ «Хакасский» обитает 40 \% видов птиц от списочного состава авифауны Республики Хакасия [9, с.125].

За исследуемый период непосредственно на исследуемом участке отмечено пребывание 17 \% видов от авифауны Республики Хакасия [10, с.86].

\section{Список литературы}

1. Анкипович E. C., 2004. Распространение редких и исчезающих видов растений на участках заповедника «Хакасский» //Научные труды заповедника «Хакасский». Вып. 3. Абакан: Изд-во «Стержень». С. 26-39.

2. Баранов A. A. Пространственно-временная динамика биоразнообразия птиц Алтай-Саянского экорегиона и стратегия его сохранения. Автореф. дисс. ...д-ра биол. наук. Улан-Удэ, 2007. 48 с.

3. Гельд Т. А. Пространственно-временная динамика населения птиц зональных и трансформированных оросительными системами степей Минусинской котловины: Автореф. дисс. ... канд. биол. наук. Улан-Удэ, 2010. 23 с.

4. Красная книга РСФСР: Растения. Москва, 1988. 350 с.

5. Прокофьев С. М. Природа Хакасии: пособие. Абакан: Хакасское кн. изд-во, 1993. $206 \mathrm{c}$.

6. Степанян Л. С. Конспект орнитологической фауны СССР. М.: Наука, 1990. 728 c.

7. Степанян Л. С. Состав и распределение птиц фауны СССР. Воробьинообразные Passeriformes. М.: Наука, 1978. 392 с.

8. Степанян Л. С. Состав и распределение птиц фауны СССР. Неворобьиные NonPasseriformes. М.: Наука, 1975. 370 с.

9. Сушкин П. П. Птицы Минусинского края, Западного Саяна и Урянхайской земли //Материалы к познанию фауны и флоры Рос. империи. Отд. зоол. Вып. 13. СПб., 1914. $551 \mathrm{c.}$

10. Сыроечковский Е. Е., Рогачева Э. В., Савченко А. П. и др. Красная книга Красноярского края /Отв. ред. А.П. Савченко. Красноярск: Краснояр. гос. ун-т, 2000. 248 c. 